\section{Iza Desperak}

Uniwersytet Łódzki

DOI: https://doi.org/10.18778/1733-8069.8.1.10

\section{RECENZJA}

DENZIN NORMAN K., LINCOLN YVONNA S., RED., (2009) METODY BADAŃ JAKOŚCIOWYCH. PRZEEOŻYLI KRZYSZTOF PODEMSKI I IN. WARSZAWA: WYDAWNICTWO NAUKOWE PWN ni kanon lektur metodologicznych? Byłoby to ze wszech miar korzystne, lecz rewolucyjność podręcznika może stanowić przeszkodę.

Jest to bowiem książka, która stawia pytania, a nie podaje gotowe nań odpowiedzi, nie jest też skryptem, z którego studenci mogliby „,zakuwać" definicje i formułki, przygotowując się do egzaminu. Jednym z pierwszych trudnych pytań jest pytanie o rolę uniwersytetu. Autorzy poświęconego jej rozdziału - Davydd J. Greenwood i Morten Levin - zaczynają od diagnozy przepaści między naukami społecznymi a społeczeństwem, a następnie postulują jej pokonanie poprzez zrekonstruowanie związków między uniwersytetami a uczestnikami życia społecznego - przede wszystkim poprzez prowadzenie badań o charakterze interwencyjnym. Czy podręcznik zaangażowanego badacza, poddający krytycznej ocenie praktyki polityczne uczelni nie jest przypadkiem zagrożeniem dla samego uniwersytetu, zwłaszcza tego, na którym pracujemy i wykładamy? Czy nie godzi w system kształcenia, w którym wszelka krytyczna refleksja jest niepożądana, a od studiujących i młodych adeptów nauki wymaga się przede wszystkim czołobitności dla autorytetów i sprawnego naśladownictwa, zwłaszcza w sferze strategii i metod badawczych?

Jest to także pierwszy podręcznik metodologiczny, w którym pojawiają się badania feministyczne i teoria queer. Poza wymienieniem przez Earla Babbiego - w jego podręczniku - paradygmatów feministycznych jako jednego z elementów współczesnego teoretycznego zaplecza nauk społecznych, nie były one dotąd obecne w polskojęzycznych podręcznikach metodologicznych. $\mathrm{W}$ rezultacie badaczki i badacze podejmu- jący badania uwzględniające perspektywę gender byli skazani albo na literaturę obcojęzyczną, albo na intuicyjne wymijanie pułapek ,ślepych na płeć" metod badawczych. Czytelniczki i czytelnicy tego dzieła otrzymują wyczerpujące studium ( $w$ rozdziale 10 pierwszego tomu, autorstwa Virginii Olesen, w przekładzie Moniki Bobako) opisujące zaplecze, historię, główne nurty i stan badań prowadzonych z perspektywy feministycznej. Pojawiają się także - chyba po raz pierwszy $\mathrm{w}$ polskim wydaniu - feministyczne strategie badawcze, które są charakterystyczne nie tylko dla różnorodnych postaci „feminizmów" akademickich, ale i dla współczesnych gender studies i socjologii (oraz zapewne etnologii) zorientowanej na gender.

Rozdział $14-\mathrm{w}$ połowie poświecony tylko teorii queer - (autorstwa Kena Plummera, znowu w przekładzie Moniki Bobako) przynosi chyba najobszerniejszą $\mathrm{w}$ języku polskim i najnowocześniejszą definicję teorii queer oraz jej zwięzły wykład. Jest to o tyle ważne, że teoria queer rozwija się w Polsce głównie wśród nauk humanistycznych i brak było dotąd wskazówek, jak z tej perspektywy prowadzić badania społeczne. Zamieszczenie $\mathrm{w}$ książce tych dwóch rozdziałów może się przyczynić zarówno do wprowadzenia do głównego nurtu badań socjologicznych perspektywy feministycznej i gender, jak i perspektywy queer.

Książka jest rewolucyjna nie tylko dlatego, że wprowadza nowe perspektywy badawcze. Zaskakujące jest też skuteczne połączenie perspektywy stricte metodologicznej z szeroko zakrojoną refleksją teoretyczną, co w dotąd wydawanych podręcznikach się nie zdarzało - mieliśmy osobne podręczniki teorii oraz osobne podręczni- ul. Rewolucji 1905 r. 41, 90-214 Łódź e-mail: idespera@uni.lodz.pl jakościowymi i etnograficznymi, czy jednak je pojawienie się na bibliotecznych półkach zmie- 
ki metodologii i metod. Choć metodologia jako taka jest ściśle zakotwiczona $\mathrm{w}$ teorii, zaplecze teoretyczne metodologii nie było dotąd tak ściśle eksponowane. Tu zaś teoria socjologiczna nie tylko znajduje swoje miejsce, ale i współtworzy refleksję metodologiczną, refleksja teoretyczna nie ogranicza się zaś do zmieniających się paradygmatów czy teorii krytycznej i ugruntowanej. Zasięg teoretyczny pracy dotyka polityki, także polityki społecznej, pedagogiki, sfery publicznej, performatywności, neokolonializmu i studiów kulturowych. Jak piszą sami autorzy, jest to projekt metodologiczny, etnograficzny, genderowy, który próbuje nakreślić stan wiedzy i praktyk metodologicznych, zwraca uwage na rolę etnografii $\mathrm{w}$ dyskursach postmodernistycznego świata. Świadomie włączają oni do swej pracy perspektywę teoretyków feminizmu, postkolonializmu i queer, ",kwestionujących tradycyjną logikę heteroseksualnej narracji tekstów etnograficznych, które refleksywnie umieszczają neutralne (lub męskie) Ja etnografa w jego realistycznej historii" (s. 12). Badaczowi jakościowemu wyznaczają rolę interpretacyjnego brikolera zorientowanego obywatelsko, który myśli historycznie, interakcyjnie i strukturalnie. Autorzy przekonują, że badania społeczne powinny powrócić do swego źródła i ponownie zostać połączone z celami społecznymi. Postulują też pozbycie się lęku przed wartościowaniem, bowiem nie istnieją badania wolne od wartości.

Problemy, z którymi ma się zmierzyć zaangażowany badacz są zdefiniowane niezwykle szeroko - od tradycyjnych obszarów badań społecznych po dylematy, przed którymi stają komisje etyczne czy nawet medyczne badania kliniczne. Podejścia badawcze, które oferują autorzy to za- równo w miarę klasyczna socjologia jakościowa, jak i przeformułowana etnografia.

Książka w swej treści i formie przeciwstawia się konserwatyzmowi metodologicznemu. Jest nieortodoksyjna jeśli chodzi o dobór tematyki, jej zawartość nie ogranicza się do omówienia wybranych metod badawczych, uzupełnionego o kontekst teoretyczny oraz etyczne i polityczne uwarunkowania badań. Przedstawia zagadnienia metodologiczne jako nierozerwalnie powiązane z teoretycznymi, stawiając jednocześnie metodę $\mathrm{w}$ centrum uwagi. Dużo miejsca poświęca się teorii krytycznej i krytycznej etnografii, teorii Michela Foucaulta jako punkcie wyjścia dla badań dyskursu i badań nazwanych przez niego archeologicznymi i, oczywiście, teorii ugruntowanej. Z kolei przegląd metod badań jest bardzo eklektyczny: mamy tu spodziewany wywiad narracyjny, obserwację, wywiady zogniskowane, grupę metod zdefiniowanych jako analiza rozmów i tekstów, jakościowe studium przypadku (autorstwa Roberta E. Stake, którego prace przekładano już wcześniej na język polski), ale także autoetnografię czy pisanie jako metodę badawczą. Metodę tę możemy poznać nie tylko $\mathrm{w}$ teorii, ale i praktyce, bo rozdział poświecony poezjom kulturowym napisany został przez Kathleen Stewart zgodnie z zasadami takiego pisania, przedstawionymi przez Laurel Richardson i Elizabeth Adams St. Pierre.

Książka ta dotyka tematów mało obecnych lub wręcz nieobecnych w polskiej literaturze przedmiotu, przełamując wiele tabu i nakreślając nowe perspektywy. Takim nieobecnym u nas tematem jest kwestia nadzoru etycznego nad badaniami, gdzie nasze lokalne praktyki znacznie odbiegaja od światowych standardów. Czy poruszenie tej problematyki przez Denzina i Lincoln przyczyni się do dyskusji na ten temat?

Język przekładu wydaje się czasem zgrzytliwy. Nie jest to chyba jednak efekt braku porozumienia między kilkoma tłumaczami i ich zakotwiczenia $\mathrm{w}$ różnych tradycjach, a raczej nieprzystawania języka pracy do standardów polskich podręczników. Książka zwraca uwagę na nieco inne niż na przykład w przywołanym podręczniku Babbiego sklasyfikowanie metod i technik - mamy więc do czynienia $\mathrm{z}$ analizą tekstów, a nie analizą treści, wywiady dzielą się na „Zwykłe” i „nieustrukturalizowane”, wywiady nazywane są raz fokusowymi, raz zogniskowanymi, co może wywołać konsternację studentów rozpoczynających dopiero swą metodologiczną edukację. Dla badaczy pragnących rozwijać swe kompetencje, jak i dydaktyków prowadzących zajęcia z metod badań jest to bardzo cenna pozycja. Być może to także zaproszenie do dialogu między badaczami reprezentującymi różne dziedziny i specjalności - od socjologów i etnologów po przedstawicieli nauk politycznych czy pedagogiki - podczas którego przedyskutowalibyśmy - trawestując tytuł jednego ze Zjazdów Socjologicznych - co nas łączy, a co dzieli. 